\title{
Larger Seeds of Winterfat Germinate Better
}

\section{H. W. SPRINGFIELD}

Highlight: Seeds of winterfat (Eurotia lanata) were separated into three size classes and germinated under four temperature regimes. Large-and medium-size seeds germinated better and faster than small-size seeds.

Larger seeds of a plant species usually produce more vigorous seedlings than smaller seeds (Kittock and Patterson, 1962). With some species-wheat, for example-seedling emergence also has been reported to be higher from larger seeds (Kittock and Law, 1968). Similar results were found with alkali sacaton (Knipe, 1970).

Germination, however, is not always greater from larger seeds. For example, little relationship was found between seed size and viability for mature seed of Hardinggrass (Whalley, et al., 1966). Likewise, size of fourwing saltbush seeds had no significant effect on germination provided the seeds contained embryos (Springfield, 1970).

The objective of this study was to determine the effects of size of winterfat (Eurotia lanata (Pursh) Moq.) seeds on their germination under four temperature regimes.

Ripe fruits of winterfat were collected in November from a group of plants ncar Corona, N. Mex. Four months later (when after-ripening was complete ${ }^{1}$ ), seeds were threshed from the fruits by hand, then separated into three size classes (Table 1).

Treatments consisted of six replications of 50 seeds each under constant temperatures of 45,51 , and $56 \mathrm{~F}$ in darkness and under an alternating regime of 76 F (12 hrs light) -60 F (12 hrs dark). Seeds were germinated in petri dishes filled with $100 \mathrm{ml}$ vermiculite and $60 \mathrm{ml}$ distilled water. Two layers of germination blotter were put on the vermiculite. The seeds, dusted with fungicide, were placed on the blotters, which remained moist throughout the experiment.

Germinated seeds were counted daily. A seed was considered germinated if the cotyledons and radicle together measured

The author is range scientist, Rocky Mountain Forest and Range Experiment Station, Albuquerque, New Mexico.

The Rocky Mt. Forest and Range Exp. Sta. maintains central headquarters at 240 West Prospect Street, Fort Collins, Colorado. The author is located at Albuquerque in cooperation with the Univ. of N. Mex.

${ }^{1}$ Unpublished results of another experiment showed after-ripening of this collection of seeds was complete in 9 weeks. 
Table 1. Characteristics of seeds.

\begin{tabular}{lccc}
\hline & Large & Medium & Small \\
\hline $\begin{array}{l}\text { Number of } \\
\text { seeds per lb. }\end{array}$ & 150,000 & 199,000 & 310,000 \\
$\begin{array}{l}\text { Length of seed (mm) } \\
\text { Average } \\
\quad \text { Range) }\end{array}$ & 3.3 & 2.8 & 2.4 \\
$\begin{array}{l}\text { Width of seed (mm) } \\
\quad \text { Average } \\
\quad(2.9-3.6)\end{array}$ & $(2.5-3.1)$ & $(2.0-2.6)$ \\
& 2.0 & 1.7 & 1.4 \\
& $(1.7-2.3)$ & $(1.5-2.0)$ & $(1.1-1.7)$ \\
\hline
\end{tabular}

Table 2. Germination of large, medium, and small seeds of winterfat at four temperatures.

\begin{tabular}{ccccc}
\hline \hline \multirow{2}{*}{$\begin{array}{c}\text { Germination } \\
\text { temperature }\left({ }^{\circ} \mathrm{F}\right)\end{array}$} & \multicolumn{4}{c}{ Percent germination (by seed size) } \\
\cline { 2 - 5 } & Large & Medium & Small & Mean1 \\
\hline 45 & 98.0 & 96.0 & 76.0 & $90.0 \mathrm{~b}$ \\
51 & 98.7 & 96.7 & 92.0 & $95.8 \mathrm{a}$ \\
56 & 99.3 & 99.3 & 94.0 & $97.5 \mathrm{a}$ \\
$76-60$ & 100.0 & 99.3 & 86.7 & $95.3 \mathrm{a}$ \\
Mean & $99.0 \mathrm{a}$ & $97.8 \mathrm{a}$ & $87.2 \mathrm{~b}$ & \\
\hline
\end{tabular}

1 Means with the same letter are not significantly different at the $5 \%$ level according to Duncan's multiple range test.
$1 / 2$ inch and both were detached from the seed coat. Germination percentages were transformed to arc sin for analysis of variance.

Germination was complete within 7 days for all seed sizes and temperatures, except for a few small seeds that germinated the 8 th and 9 th day under the $45 \mathrm{~F}$ temperature.

Total germination was higher for large and medium seeds than for small seeds under all four temperature regimes (Table 2 ). The greatest difference between germination of small and large seeds came under the lowest temperature. Subtle biochemical differences related to size and influenced by temperature may explain why large seeds germinated $98 \%$ but small seeds only $76 \%$ under a temperature of $45 \mathrm{~F}$.

The relatively low germination of small seeds under 76-60 F, compared with large and medium sceds, is not easily explained. Apparently the small seeds are more sensitive to external conditions and therefore are less likely to produce seedlings in a field environment.

The larger seeds germinated more rapidly than the small seeds under all four temperatures (Fig. 1). Differences in speed of germination between large and small seeds were greatest under temperatures of 45 and 51 ; for example, at 51, $93 \%$ of the large seed had germinated by the 4 th day, as against only $41 \%$ of the small seed. The faster germination of the larger seeds may be attributed to greater amounts of essential constituents available to the developing seedling (Mayer and Poljakoff-Mayber, 1963). This is further implied through results with germinating wheat; significant relationships were found between seed size and tetrazolium reduction, a biochemical index of vigor (Kittock and Law, 1968).

Maximum germination of the smaller seeds may be possible only when external factors, like moisture and temperature, are nearly optimum. Results of other studies (Springfield, 1972) suggest that $45 \mathrm{~F}$ is below the optimum temperature range for germination of winterfat.

\section{Literature Cited}

Kittock, D. L., and A. G. Law. 1968. Relationship of seedling vigor to respiration and
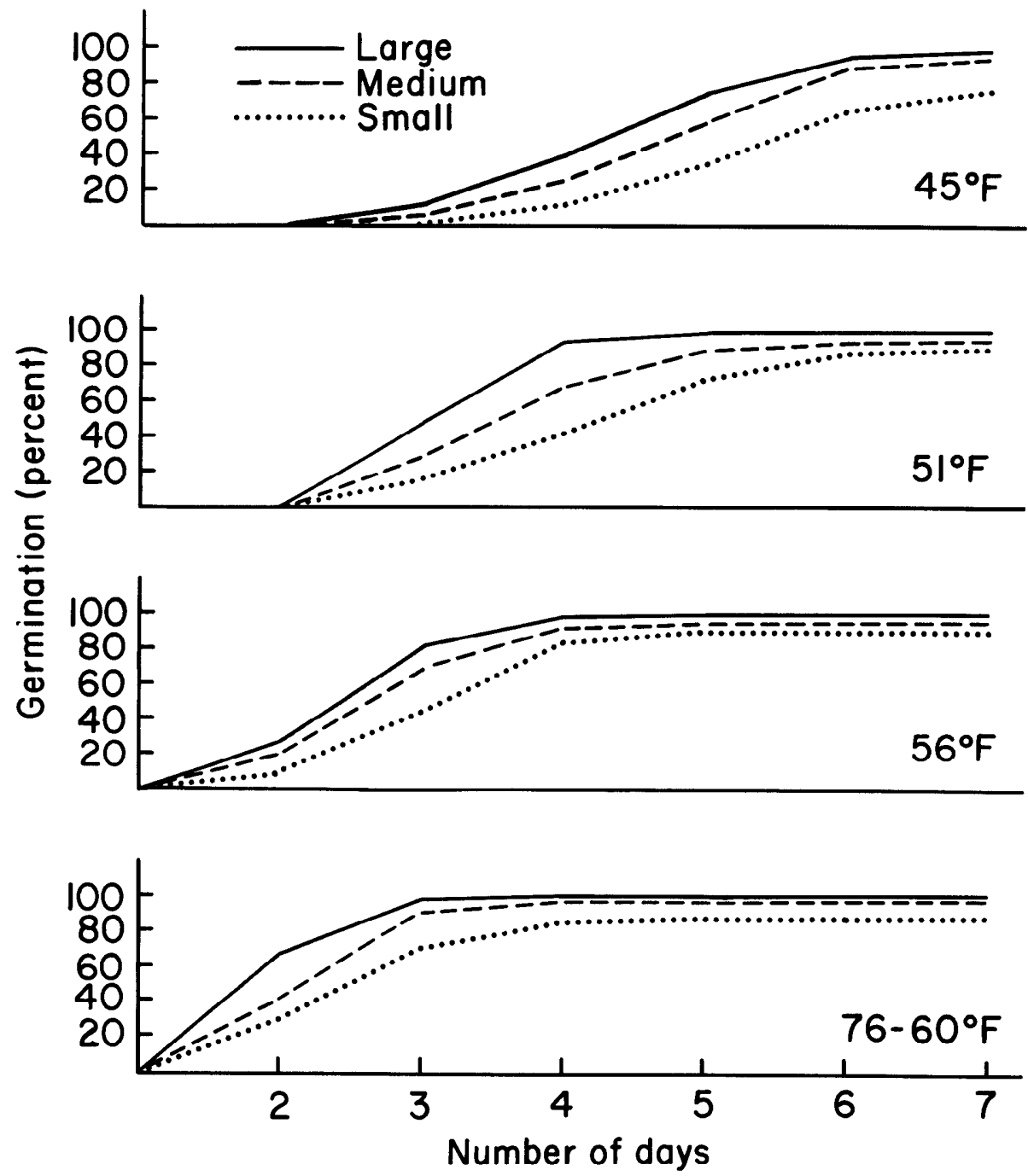

Fig. 1. Speed of germination of large, medium, and small seeds under four temperature regimes.

tetrazolium chloride reduction by germinating wheat seeds. Agron. J. 60:286-288.

Kittock, D. L., and J. K. Patterson. 1962. Seed size effects on performance of dryland grasses. Agron. J. 54:277-278.

Knipe, O. D. 1970. Large seeds produce more, better alkali sacaton plants. J. Range Manage. 23:369-371.

Mayer, A. M., and A. Poljakoff-Mayber. 1963. The germination of seeds. Pergamon Press, MacMillan Co., New York, 236 p.

Springfield, H. W. 1970. Germination and establishment of fourwing saltbush in the Southwest. Rocky Mt. Forest and Range Exp. Sta., USDA Forest Serv. Res. Pap. RM-55, 48 p.

Springfield, H. W. 1972. Optimum temperatures for germination of winterfat. J. Range Manage. 25:69-70.

Whalley, R. Derwyn B., Cyrus M. McKell, and Lisle R. Green. 1966. Seed physical characteristics and germination of Hardinggrass (Phalaris tuberosa var. stenoptera [Hack.] Hitch.). J. Range Manage. 19:129-132. 